\title{
Two organic carbon application rates to control inorganic nitrogen in minimal water exchange, biofloc, shallow water, shrimp nursery systems
}

\author{
Jack Crockett ${ }^{\star 1}$ and Addison Lawrence ${ }^{1,2,3}$ \\ ${ }^{1}$ Texas A\&M University AgriLife Research Mariculture Laboratory, Port Aransas, \\ TX 78373 USA \\ ${ }^{2}$ Department of Wildlife and Fisheries Science, Texas A\&M University College \\ Station, TX 77843-2258 USA \\ ${ }^{3}$ Department of Biological Sciences Texas A\&M University-Corpus Christi, \\ Corpus Christi, TX 78412-5843 USA
}

\begin{abstract}
A B S T R A C T
The objectives of this study were to develop and test a quantitative method for reactive carbon application to control inorganic nitrogen, and to compare the effect of carbon application using $40 \%$ and $60 \%$ microbial conversion efficiency (MCE) while leaving a residual $11.3 \mathrm{mg} / \mathrm{l}$ nitrate nitrogen $\left(\mathrm{NO}_{3}-\mathrm{N}\right)$ level. The organic carbon requirement was based on the carbon to nitrogen ratio of the elemental composition of microbial cells. The source of supplemental organic carbon was shortchained fructooligosaccharide ( $\mathrm{scFOS}$ ). Correction for moisture was duplicated on the first 2 days of scFOS application, so the actual efficiency rates were $35.1 \%$ and $58.3 \%$. The proposed carbon quantitative method was effective in predicting the amount of carbon required to control inorganic nitrogen. Both 35.1\% MCE and 58.3\% MCE maintained total ammonia nitrogen (TAN) and nitrite nitrogen $\left(\mathrm{NO}_{2}-\mathrm{N}\right)$ at desired levels of equal to or less than $2.3 \mathrm{mg} / \mathrm{l}$ and $3.1 \mathrm{mg} / \mathrm{l}$, respectively. The amount of carbon applied using $35.1 \%$ MCE was higher than with 58.3\% MCE. The 58.3\% MCE treatment resulted in slightly higher $\mathrm{NO}_{3}-\mathrm{N}$ levels than $35.1 \% \mathrm{MCE}$. The most toxic species of inorganic nitrogen, TAN and $\mathrm{NO}_{2}-\mathrm{N}$, are assimilated by heterotrophic bacteria before $\mathrm{NO}_{3}-\mathrm{N}$, permitting decreased reactive carbon input and water quality improvement. The benefits of $58.3 \%$ MCE vs. 35.1\% MCE were lower organic loading, reduced water replacement, and decreased costs. The total water replacement associated with biofloc control was $0.24 \%$ using $35.1 \% \mathrm{MCE}$ and $0 \%$ using 58.3\% MCE. After a culture period of 14 days the mean weight was $65.5 \mathrm{mg}$ and $61.9 \mathrm{mg}$ for $31.5 \% \mathrm{MCE}$ and $58.1 \% \mathrm{MCE}$, respectively, and a survival of $79.5 \%$ for both MCE's.
\end{abstract}

Keywords: Biofloc, minimal water exchange, shallow water systems, inorganic nitrogen control, short chained fructooligosaccharide

\section{Introduction}

For a number of years shallow water biofloc nurseries have been used to successfully produce juvenile Litopenaeus vannamei, Pacific white-legged shrimp, at Texas AgriLife Research Mariculture laboratory in Port Aransas, Texas. The focus of simulated production trials has been to develop a method for commercial production of juvenile shrimp at inland sites where seawater is not available. The reduction of salinity in water used within recirculating aquaculture systems can lead to production of shrimp at lower costs because of the need for less salt and easier management of wastewater (Schuler et al. 2010). Ammonia and nitrite toxicity increases as salinity decreases. (Lin and Chen, 2001; Lin and Chen, 2003). High nitrate nitrogen levels are detrimental to shrimp, especially at low salinity, as they can reduce growth, decrease survival, and cause negative effects on product marketability (Kuhn et al. 2010). Initial simulated produc-

Corresponding author email: smpjke@yahoo.com tion trials were carried out in full strength seawater (28 ppt), however, the objective was to develop an acceptable minimal water exchange process, before testing it in low salinity water where the inorganic nitrogen level is more critical.

During initial biofloc trials, ammonia and nitrite levels were controlled throughout the entire production trial primarily through oxidation by nitrifying bacteria in autotrophic dominant biofloc (Crockett et al. 2012). Both ammonia and nitrite were kept at levels acceptable for shrimp culture in low salinity water, however, this technique resulted in nitrate nitrogen levels higher than optimal for low salinity shrimp culture. The end product of nitrification is nitrate nitrogen (Rittmann and McCarty 2001). Attempts were made to dilute nitrates, however, the result was a spike in nitrite nitrogen (Crockett et al. 2012). Water exchange rates above $30 \%$ per day wash more nitrifying bacteria out of a system than the amount required to maintain steady nitrification (Avnimelech 2009).

An option to reduce nitrate nitrogen levels was to provide enough organic carbon for heterotrophic bacteria to assimilate ammonia and nitrites rather than allowing nitri- 
fying bacteria to oxidize these types of inorganic nitrogen to nitrates. A methodology was developed to control inorganic nitrogen by sequencing autotrophic and heterotrophic bacterial dominance (Crockett et al. 2013). In this process ammonia and nitrite nitrogen were initially controlled through oxidation, followed by inorganic nitrogen bacterial assimilation. When enough suspended particulate matter within the water column had been established to serve as media on which heterotrophic bacteria colonies could develop, heterotrophic dominance was promoted.

Organic carbon is required for heterotrophic bacteria to assimilate inorganic nitrogen for cell synthesis (Rittmann and McCarty 2001). Nitrogen input was reduced at the same time organic carbon input was increased by decreasing the feed protein level. Organic carbon input was also increased by applying a carbon source to reduce the concentration of inorganic nitrogen in the production system. A methodology was developed to keep inorganic nitrogen levels close to zero (Crockett, et al. 2013).

However, it is desirable to have a residual level of nitrate nitrogen for proactive prevention of sulfates being reduced to hydrogen sulfide, should anaerobic pockets develop (Churchhill and Elmer 1999, US Peroxide 2014). Low levels of nitrates (up to $35 \mathrm{mg} / \mathrm{l}$ ) are not detrimental to shrimp, even at greatly reduced salinities (Kuhn et al. 2010). Less organic carbon application is required if low levels of nitrate nitrogen remain in the system. If less organic carbon is applied, there is less the organic loading and production costs.

One of the objectives of this trial was to develop a quantitative method to determine the amount of organic carbon required to assimilate total ammonia nitrogen, nitrite nitrogen, and a selected level of nitrate nitrogen. The targeted residual nitrate nitrogen concentration was approximately $11 \mathrm{mg} / \mathrm{l}$.

Studies using stoichiometric analysis have reported that heterotrophic bacteria require 6.07 grams of organic carbon for each gram of total ammonia nitrogen (TAN) assimilated (Ebeling et al. 2006). In these studies it was assumed the system was pure heterotrophic bacteria, and no autotrophic bacteria were present. It was concluded that if enough organic carbon is present to assimilate TAN, there is no production of nitrite nitrogen $\left(\mathrm{NO}_{2}-\mathrm{N}\right)$ or nitrate nitrogen $\left(\mathrm{NO}_{3}-\mathrm{N}\right)$.

It has also been reported that there are no totally autotrophic and no totally heterotrophic systems, and there is always a mix between the two types of bacteria (Avnimelech 2009). When sequencing autotrophic and heterotrophic dominance, autotrophic bacteria are initially inoculated, followed by promotion of heterotrophic bacterial dominance. In this study it was assumed both autotrophic and heterotrophic bacterial populations were present, and that both oxidation and assimilation of inorganic nitrogen was occurring simultaneously.

Ammonia nitrogen can be assimilated relatively easily by heterotrophic bacteria because it is more reduced than other forms of inorganic nitrogen. Nitrate and nitrite must be reduced by enzymes to ammonia before assimilation occurs, but all types of inorganic nitrogen can be incorporated into organic material by heterotrophic bacteria if organic carbon is available (Prescott et al. 1990). It was accepted the carbon requirement for nitrogen in TAN, $\mathrm{NO}_{2}-\mathrm{N}$, and $\mathrm{NO}_{3}-\mathrm{N}$ needed to be taken into consideration to determine the amount of organic carbon required.

It was assumed the amount of organic carbon required to assimilate inorganic nitrogen is proportional to the ratio of carbon and nitrogen in microbial cells. Bacteria have a large range of carbon and nitrogen levels. Mean values were selected to be the base for the calculations for the addition of organic carbon. Means of the percentage ranges give an average carbon to nitrogen ratio of 5.17:1. Table 1 provides information concerning the carbon, oxygen, hydrogen, and nitrogen values used in this study.

Table 1. The chemical composition of prokaryotic cells resulting in mean carbon to nitrogen ratio of 5.17:1.

\begin{tabular}{lcc}
\hline Element & Percentage Range $^{1}$ & Mean Percent $^{2}$ \\
\hline Carbon & $45-55$ & 48.9 \\
Oxygen & $22-28$ & 24.8 \\
Hydrogen & $5-7$ & 5.2 \\
Nitrogen & $8-13$ & 9.46 \\
\hline
\end{tabular}

${ }^{1}$ (Rittmann and McCarthy, 2001)

${ }^{2}$ (Avnimelech, 2009)

The potential microbial biomass that can be generated from inorganic nitrogen was projected using $9.46 \%$ nitrogen biomass content. The required amount of carbon to become bacterial tissue was estimated using $48.9 \%$ carbon biomass content.

During metabolism some organic carbon is lost as carbon dioxide due to cellular respiration through catabolism and some carbon becomes microbial biomass through anabolism (Rittman and McCarty 2001). The percentage of assimilated carbon with respect to metabolized feed carbon is defined as the microbial conversion efficiency and is in the range of 40-60\% (Avnimelech 2009). The primary objective of this study was to compare two microbial conversion efficiency (MCE) rates (40\% and 60\%).

\section{Materials and Methods}

\subsection{Aquaculture System}

Four $1.5 \mathrm{~m}$ square tanks were filled with filtered 28 ppt seawater to a depth of $20 \mathrm{~cm}$. Each tank contained five aeration hoses, a submersible heater, an automatic belt feeder, and $8 \mathrm{~mm}$ square netting suspended into the water column to increase surface area and to mitigate water circulation. The dissolved oxygen level was maintained above $5 \mathrm{mg} / \mathrm{l}$, the temperature was kept at $28 \pm 1^{0}$ centigrade, and the feeders were loaded once every 24 hours in the morning.

Each tank was equipped with a settling tank used to remove excess biofloc. Water was moved into the settling tank by an airlift pump which had a 0.5 to 0.8 liter per minute capacity. Treated water returned to the culture tank by gravity.

Low light level (36 lumens per $\mathrm{m}^{2}$ ), which is beneficial for nitrifying bacteria development, was maintained except for brief periods when system maintenance was being carried out.

\subsection{Stocking Procedure}

Post-larvae were provided by Shrimp Improvement Systems, Islamorada, Florida. The tanks were stocked with $\mathrm{PL}_{13} \mathrm{Li}$ topenaeus vannamei (mean size $3.7 \mathrm{mg}$ ) at an average density of $3,295 / \mathrm{m}^{2}\left(16,475 / \mathrm{m}^{3}\right)$. The number of animals stocked were counted at the hatchery, and upon arrival were counted again using an XpertSea Solutions, Inc. electronic counter.

The post-larvae were acclimated to the salinity, $\mathrm{pH}$, temperature, and overall tank water conditions over a 90 minute period. No mortality or stress were observed. As soon as the animals were released into the tank feed was proffered. 
$\frac{\left(\frac{200 \mathrm{mg} / \mathrm{l} \text { - actual alkalinity in } \mathrm{mg} / \mathrm{l}}{\text { Concentration of } \mathrm{HCO}_{3} \text { in } \mathrm{Na} \mathrm{HCO}_{3}}\right) \mathrm{X} \text { tank volume in liters }}{1000 \mathrm{mg} / \mathrm{l}}=$ grams $\mathrm{NaHCO}_{3}$ required per tank

\subsection{Hydrological Parameters and Water Quality}

Dissolved oxygen, temperature, and salinity were measured once daily with an YSI 85 oxygen conductivity, salinity and temperature meter (YSI, Yellow Springs, OH). Municipal fresh water, treated by reverse osmosis, was added as needed to replace water lost by evaporation.

Total ammonia nitrogen, nitrite nitrogen, nitrate nitrogen, $\mathrm{pH}$, and alkalinity, were monitored every morning and afternoon. Tetra test strips (Tetra, Blacksburg, VA) were used to get rapid results on inorganic nitrogen levels. Standard inorganic nitrogen solutions were used to validate test strip readings. On a weekly basis test strip values for ammonia and nitrite were compared to Hach DR3900 (HACH Company, Loveland, CO) analysis results. Samples were sent to an independent lab for comparison of nitrate nitrogen values.

Settleable solids were determined twice daily with Imhoff cones at 7:00 a.m. and 4:00 p.m. These values were used to define the biofloc level.

\subsection{Feeding Regime}

The daily estimated population was adjusted for expected mortality. Four samples from each tank averaging 90 animals each were taken during the culture period. The average weights were used to adjust the feeding curves which were based on known growth rates. The expected weight gain per animal was multiplied by the number of animals per tank times the FCR to quantify the daily feed ration. Tank bottoms were checked every morning after the feeding cycle was over to check for uneaten feed. The percentage of protein in the feed is described in the sections on bacterial dominance.

\subsection{Autotrophic Dominance}

Autotrophic dominance was promoted until biofloc levels reached a minimum of $3 \mathrm{ml} / \mathrm{l}$. During this period $41.3 \%$ protein (on an as-used basis) feed was given to provide complete nutritional requirements. The carbon to nitrogen ratio $(\mathrm{C}: \mathrm{N})$ of this feed is low (about 7.8:1 on an asused basis), which limits the amount of carbon available for heterotrophic bacteria to assimilate inorganic nitrogen, restricting their competition with autotrophic bacteria.

To rapidly initiate a population of nitrifying bacteria, the tanks were inoculated with commercial inoculum (Fritz Turbostart 900, Fritz Industries, INC., Mesquite, TX ) at a rate of $0.2 \mathrm{ml} / \mathrm{l}(90 \mathrm{ml} / \mathrm{l}$ per tank) immediately after the shrimp were stocked. Thereafter, every morning at 7:00 a.m. and every afternoon at 4:00 p.m. inorganic nitrogen was monitored with test strips. If the total ammonia level was $2 \mathrm{mg} / \mathrm{l}$ or higher, $90 \mathrm{ml}$ of inoculum was applied. If the $\mathrm{NO}_{2}^{-}$level was $2 \mathrm{mg} / \mathrm{l}$ or greater an additional $90 \mathrm{ml}$ of inoculum was applied. The nitrifying bacteria inoculum was applied as needed during the period autotrophic dominance was being promoted, and on the first day of transition from autotrophic to heterotrophic dominance.

\subsection{Alkalinity Management}

Sodium bicarbonate was added to the tank water to maintain alkalinity and $\mathrm{pH}$ at desired levels $(160 \mathrm{mg} / \mathrm{l}$ to $200 \mathrm{mg} / \mathrm{l}$ and 7.5 to 8.6 , respectively). Sodium bicarbonate was applied when the level dropped to $160 \mathrm{mg} / \mathrm{l}$ or lower using a formula defined by Crockett et al. (2012). See Equation 1 for sodium bicarbonate required to raise alkalinity to $200 \mathrm{mg} / \mathrm{l}$.

\subsection{Heterotrophic Dominance}

When Imhoff cone readings indicated the biofloc levels were greater than $3 \mathrm{ml} / 1$ heterotrophic dominance was promoted. The feed was changed to $21.5 \%$ protein (on an as-used basis) which reduced the C:N ratio to about $15: 1$. To further increase the C:N ratio, scFOS was applied daily in proportion to existing inorganic nitrogen levels. In this manner, enough organic carbon was available for heterotrophic bacteria to be dominate.

It was assumed all inorganic nitrogen in the system was available to be assimilated by heterotrophic bacteria and become microbial biomass. The potential microbial biomass resulting from assimilation of inorganic nitrogen is directly proportional to the amount of inorganic nitrogen in the system. For each part of microbial biomass there are 0.0946 parts of nitrogen. Therefore, inorganic nitrogen divided by 0.0946 is equal to potential microbial biomass. Selected inorganic nitrogen was calculated using the sum of $\mathrm{mg} / \mathrm{l} \mathrm{TAN}$, $\mathrm{mg} / \mathrm{l} \mathrm{NO}_{2}-\mathrm{N}$ and $\mathrm{NO}_{3}-\mathrm{N}$ above $11.3 \mathrm{mg} / \mathrm{l}$. For each part of potential microbial biomass there are 0.489 parts of carbon, so this proportion was used to calculate the amount of carbon required to be assimilated by potential microbial biomass.

Equation 2 shows the hypothetical quantification of potential microbial biomass from a selected level of inorganic nitrogen, and determination of the amount of carbon required for inorganic nitrogen assimilation. The amount of carbon in $\mathrm{mg} / \mathrm{l}$ was converted to grams of carbon required per tank.

$$
\frac{\begin{array}{c}
\mathrm{TAN} \text { mg/l }+\mathrm{NO}_{2}-\mathrm{N} \mathrm{mg} / \mathrm{l}+ \\
\left(\mathrm{NO}_{3}-\mathrm{N} \mathrm{mg} / \mathrm{l}>11.3\right)
\end{array}}{0.0946}-\begin{aligned}
& \text { potential microbial bio- } \\
& \text { mass derived from } \\
& \text { selected level of inorganic } \\
& \text { nitrogen }
\end{aligned}
$$

\begin{tabular}{|c|c|c|c|}
\hline $\begin{array}{l}\text { Potential } \\
\text { microbial } \\
\text { biomass }\end{array}$ & $\mathrm{X}$ & $\begin{array}{l}0.489 \text { (decimal } \\
\text { equivalent of } \\
\% \mathrm{C} \text { in } \\
\text { microbial bio- } \\
\text { mass) }\end{array}$ & $\begin{array}{l}\text { Amount of carbon } \\
\text { - in mg/l) required by } \\
\text { microbes to assimilate } \\
\text { selected level of inor- } \\
\text { ganic nitrogen }\end{array}$ \\
\hline
\end{tabular}$$
\% \mathrm{~N} \text { in microbial bimass) }
$$

The carbonaceous substance to apply (with $100 \%$ efficiency) was determined by adjusting for moisture and percent carbon. See Equation 3 for the equations used 


$$
\begin{aligned}
& \frac{\mathrm{mg} \text { carbon /i required by microbes }}{1,000 \mathrm{mg} / \mathrm{l}} \times \text { volume (1) of tank }=\underset{\text { apply per tank }}{\text { grams of carbon to }} \\
& \frac{\text { grams of carbon to apply per tank }}{\text { decimal equivalent of \% carbon }}=\begin{array}{l}
\text { grams of carbonaceous } \\
\text { substance to apply with } \\
100 \% \text { efficiency }
\end{array} \\
& \text { in carbonaceous substance }
\end{aligned}
$$

to calculate the amount of carbon required, and the amount of carbonaceous substance to apply to each tank.

The source of carbon used for reactive control of inorganic nitrogen was short-chained fructooligosaccharide (scFOS) which is a prebiotic having $40.98 \%$ carbon on an as-used basis. ScFOS was applied to convert excess inorganic nitrogen to bacterial biomass in two tanks at $40 \% \mathrm{MCE}$ and two tanks at $60 \%$ MCE. Equation 4 gives the equation used to determine the amount of scFOS to apply for both $40 \%$ MCE and $60 \%$ MCE.

grams of carbonaceous substance to apply with $100 \%$ efficiency

decimal equivalent of specified $\operatorname{MCE}(0.4$ or 0.6$)$

$=\quad$ grams of scFOS

\section{Results and Discussion}

Correction for moisture was duplicated on the first two days of scFOS application, so the actual microbial conversion efficiency rates turned out to be $35.1 \%$ and $58.3 \%$ rather than $40 \%$ and $60 \%$.

Table 2. Mean daily hydrological parameters, and biofloc. Mean harvest weight, survival, water replacement, and FCR. The values are means of two replicates per treatment.

\begin{tabular}{lcc}
\hline \multicolumn{1}{c}{ Parameter } & $35.1 \% \mathrm{MCE}$ & $58.3 \% \mathrm{MCE}$ \\
\hline Dissolved oxygen $(\mathrm{mg} / \mathrm{l})$ & 6.24 & 6.29 \\
Temperature $\left({ }^{\circ} \mathrm{C}\right)$ & 27.60 & 27.53 \\
Salinity(ppt) & 28.68 & 28.63 \\
Biofloc (ml/l) & 6.32 & 6.08 \\
Harvest weight (mg) & 65.5 & 61.9 \\
Survival (\%) & 79.5 & 79.5 \\
Water Replacement (\%) & 0.24 & 0 \\
FCR & 1.6 & 1.5 \\
\hline
\end{tabular}

Table 2 details mean hydrological parameters, mean biofloc levels, mean harvest weights, mean survivals, mean water replacement, and mean FCR. Mean parameters were very similar and not significantly different for both treatments. However, mean biofloc levels were slightly higher in treatment $35.1 \% \mathrm{MCE}$, and settling was required to keep levels within those specified by trial standards. Approximately $0.24 \%$ water replacement was needed to make up for what was lost during biofloc removal. Treatment 58.3\% MCE did not require biofloc settling or water replacement. The harvest weight was slightly higher for the $35.1 \%$ MCE treatment.
Table 3. Mean TAN, $\mathrm{NO}_{2}-\mathrm{N}$ and $\mathrm{NO}_{3}-\mathrm{N}$ for $35.1 \%$ and $58.3 \%$ microbial conversion efficiency rates. The values are daily means of two replicates per treatment in $\mathrm{mg} / \mathrm{l}$ nitrogen.

\begin{tabular}{lccc}
\hline Parameter & Period & 35.1\%MCE(mg/l) & 58.3\%MCE(mg/l) \\
\hline \multirow{2}{*}{ TAN } & Day 6 & 1.92 & 1.92 \\
& Days 6-14 & 0.67 & 0.71 \\
& Day 14 & 0.19 & 0.19 \\
\hline \multirow{2}{*}{$\mathrm{NO}_{2}-\mathrm{N}$} & Day 6 & 3.04 & 3.04 \\
& Days 6-14 & 0.94 & 0.99 \\
& Day 14 & 0.53 & 0.61 \\
$\mathrm{NO}_{3}-\mathrm{N}$ & Day 6 & 11.86 & 11.30 \\
& Days 6-14 & 10.23 & 12.18 \\
& Day 14 & 11.30 & 13.50 \\
\hline
\end{tabular}

Table 3 details the mean levels of inorganic nitrogen for both treatments during heterotrophic dominance promotion. ScFOS was applied in all tanks on a daily basis during the heterotrophic phase (days 6 through 13). Mean TAN and $\mathrm{NO}_{2}-\mathrm{N}$ were very similar for both treatments during this period. At the beginning of the heterotrophic phase (day 6), mean $\mathrm{NO}_{3}-\mathrm{N}$ values were very similar for both treatments. Mean $\mathrm{NO}_{3}^{3}-\mathrm{N}$ during the entire heterotrophic period (days 6 through 14) was slightly higher in the $58.3 \%$ MCE treatment.

Details on daily and accumulated scFOS applications are shown in table 4 . During the first 3 days heterotrophic dominance was stimulated, mean daily scFOS applications were greater for the 35.1\% MCE treatment. Thereafter, the amount of daily scFOS applied for both treatments were more similar. Accumulated scFOS applied was greater for the $35.1 \%$ MCE treatment.

Table 4. Daily and accumulated scFOS application for 35.1\% and $58.3 \%$ microbial conversion efficiency rates. The values are means of two replicates per treatment in grams.

\begin{tabular}{ccccc} 
& \multicolumn{2}{c}{ Daily } & \multicolumn{2}{c}{ Accumulated } \\
\hline Day & $35.1 \%$ MCE & $58.3 \%$ MCE & $35.1 \%$ MCE & $58.3 \%$ MCE \\
\hline 6 & 86.20 & 44.50 & 86.20 & 44.50 \\
7 & 29.35 & 17.90 & 115.55 & 62.40 \\
8 & 12.25 & 7.45 & 127.80 & 69.85 \\
9 & 28.75 & 29.35 & 156.55 & 99.20 \\
10 & 34.03 & 34.40 & 190.55 & 133.60 \\
11 & 24.20 & 33.45 & 214.78 & 167.05 \\
12 & 17.65 & 24.35 & 232.43 & 191.40 \\
13 & 51.80 & 48.35 & 284.23 & 239.75 \\
\hline
\end{tabular}




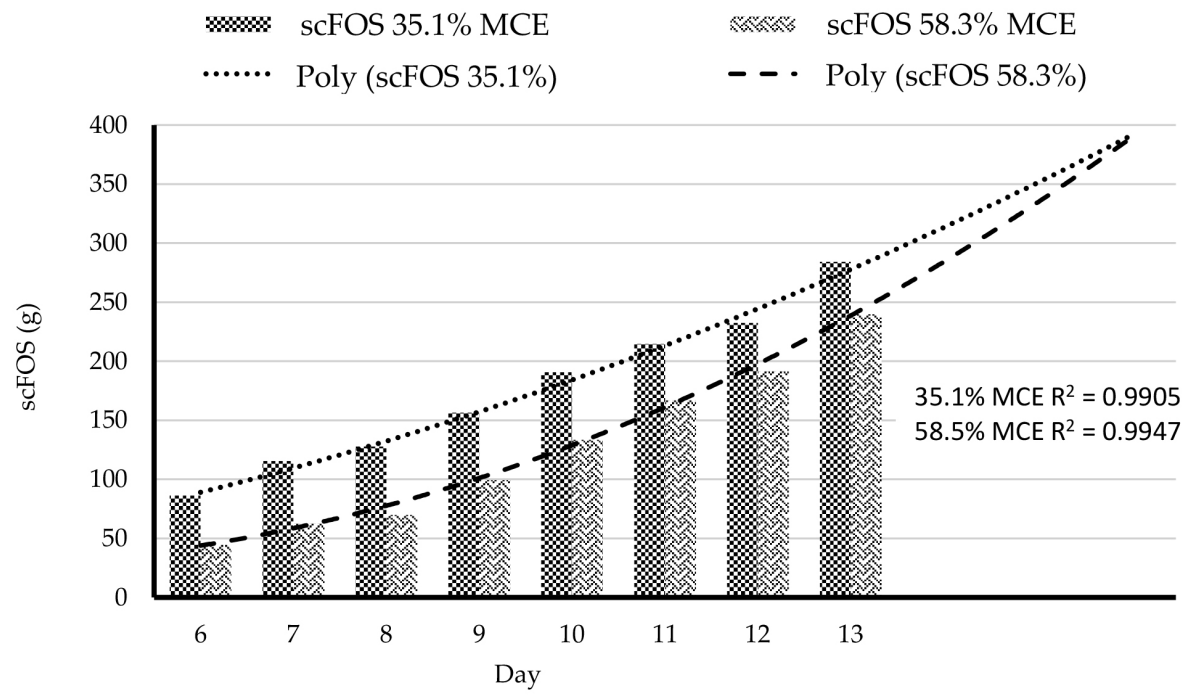

Figure 1. Trends of accumulated scFOS application for both MCE rates projected forward 3 periods.

Figure 1 shows trends of accumulated scFOS for both application rates projected forward 3 periods (days). The difference between the amounts of accumulative scFOS for each treatment, progressively decreased with time. These trends intersect indicating the same amount of scFOS may have been estimated for both treatments in the future. If this is true, the sum of inorganic nitrogen would have to be higher for the 58.3\% MCE rate and lower for the 35.1\% MCE rate.

TAN, $\mathrm{NO}_{2}-\mathrm{N}$, and $\mathrm{NO}_{3}-\mathrm{N}$ levels as compared to daily carbon application for both treatments are given in Figure 2. In both treatments TAN and $\mathrm{NO}_{2}-\mathrm{N}$ were assimilated before $\mathrm{NO}_{3}-\mathrm{N}$. Mean daily TAN and ${ }^{2} \mathrm{NO}_{2}-\mathrm{N}$ levels were very similar for both treatments even though more organic carbon was applied in the $35.1 \%$ MCE treatment. TAN levels did not increase above $2 \mathrm{mg} / \mathrm{l}$ and $\mathrm{NO}_{2}-\mathrm{N}$ did not increase above $3.1 \mathrm{mg} / \mathrm{l}$ during the experimental period.

\section{$35.1 \%$ Efficiency}
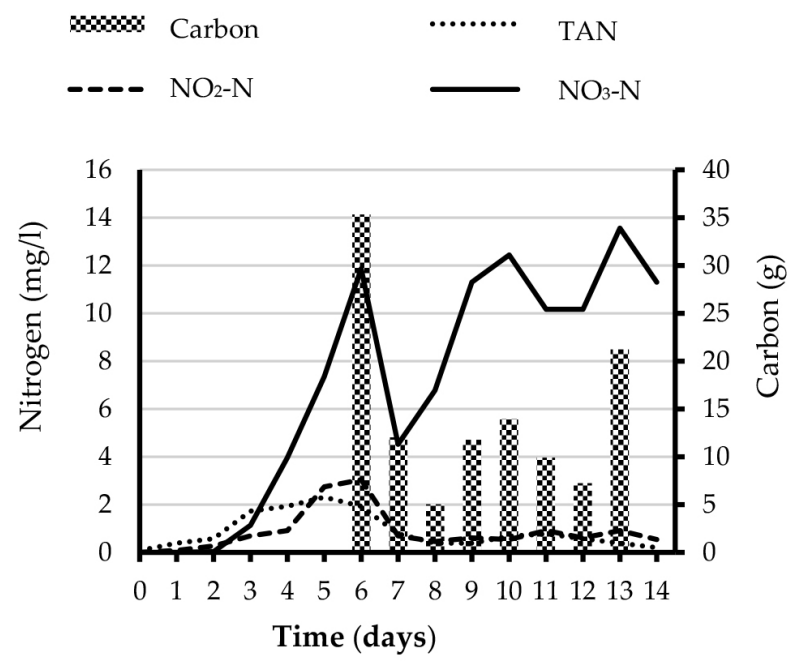

Figure 3. shows accumulated carbon as compared to inorganic nitrogen. Total accumulative scFOS applications were 0.6312 and $0.5327 \mathrm{~g} / \mathrm{l}$ in treatments $35.1 \% \mathrm{MCE}$ and $58.3 \%$ MCE, respectively. At trial termination $15.65 \%$ less scFOS was applied in the 58.3\% MCE treatment. This occurred because the lower efficiency rate called for a greater application rate.

Figure 4 compares TAN, $\mathrm{NO}_{2}-\mathrm{N}$ and $\mathrm{NO}_{3}-\mathrm{N}$ for both treatments. 35.1\% MCE carbon application rate was more precise in maintaining nitrate nitrogen at the selected level (11.3 $\mathrm{mg} / \mathrm{l})$. Mean daily nitrate levels in treatment $58.3 \% \mathrm{MCE}$ were slightly higher resulting an average of $1.88 \mathrm{mg} / \mathrm{l} \mathrm{NO}_{3}-\mathrm{N}$ greater than selected. The differences were not significant.

There was not enough carbon in the $21.5 \%$ protein feed to assimilate enough inorganic nitrogen to maintain the desired level of $11.3 \mathrm{mg} / \mathrm{l} \mathrm{NO}_{3}-\mathrm{N}$ residual nitrate. Daily scFOS applications were required to reduce

Figure 2. Daily scFOS carbon applications compared to organic mitrogen levels. 


\section{$35.1 \%$ Efficiency}

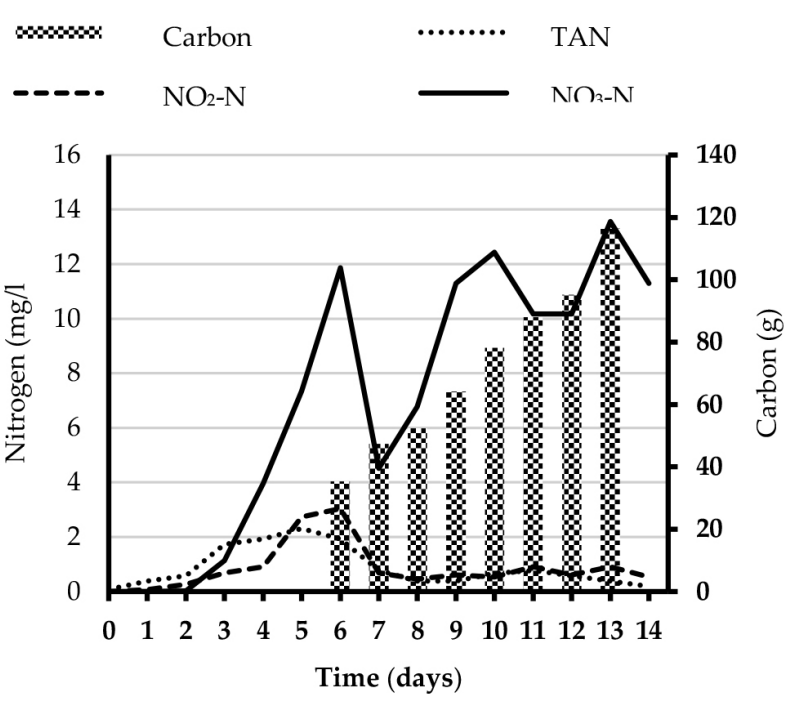

$58.3 \%$ Efficiency
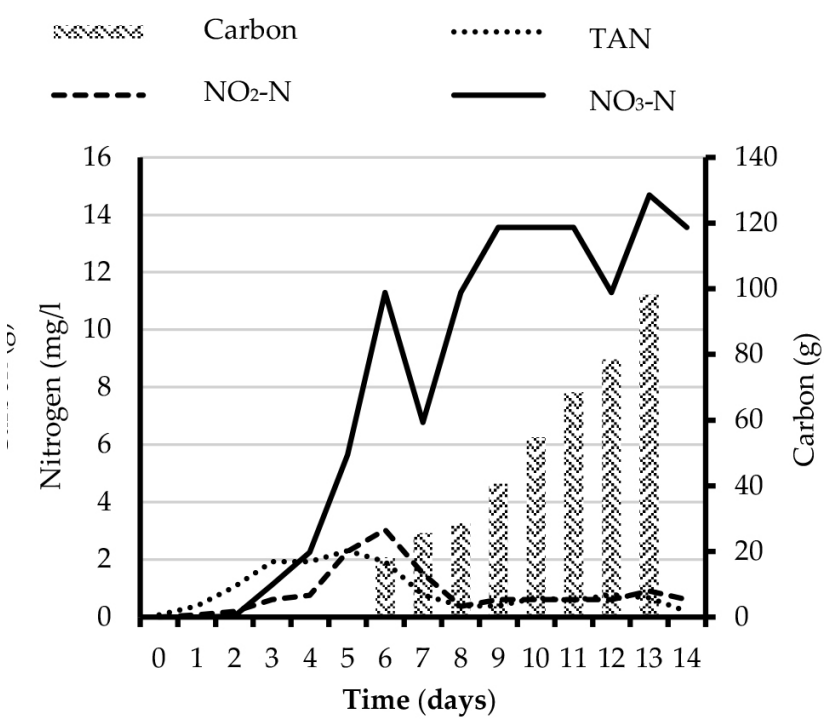

Figure 3. Accumulative scFOS carbon applications compared to inorganic nitrogen levels.

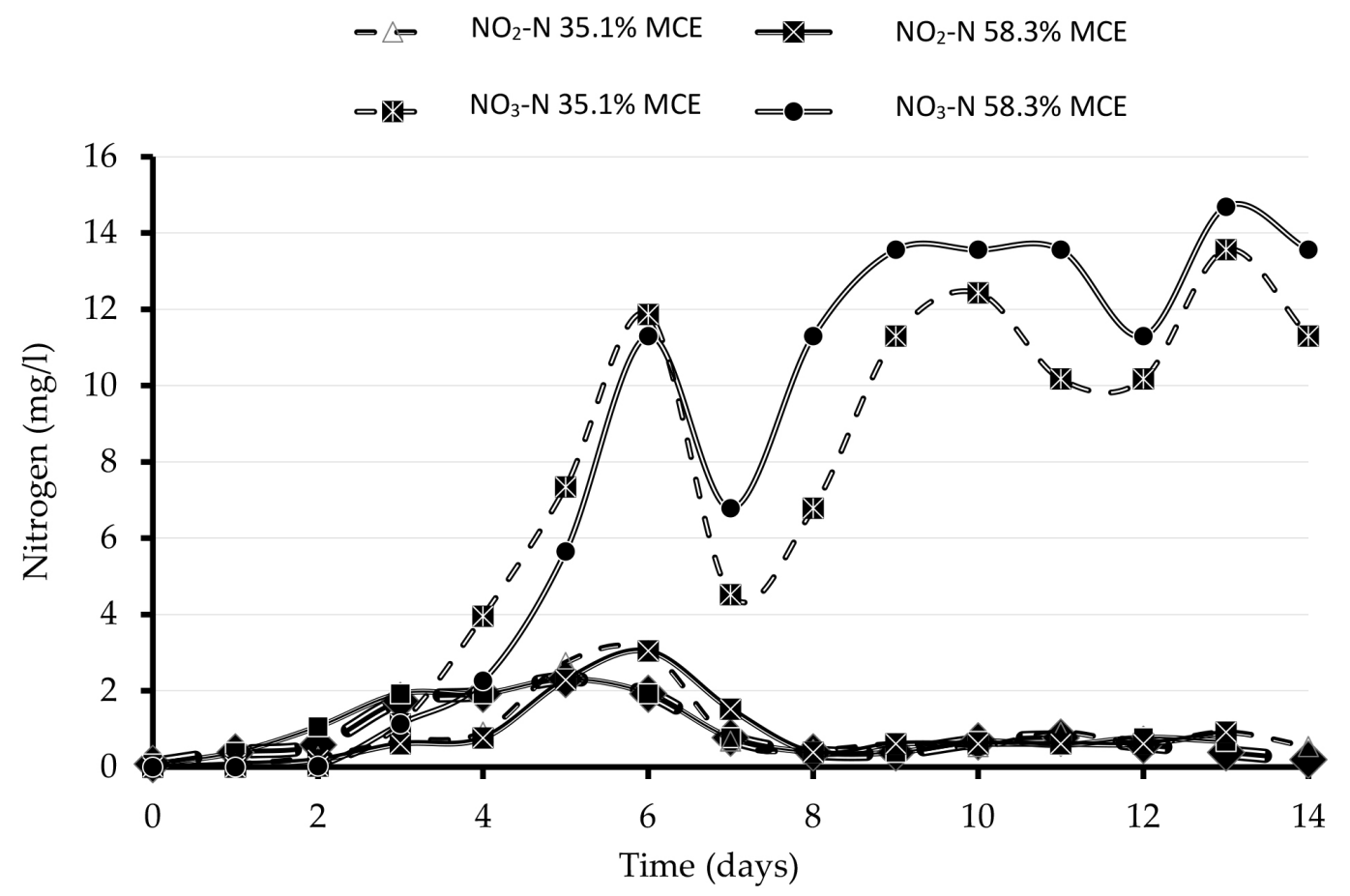

Figure 4. Inorganic nitrogen levels with $35.1 \%$ and $58.3 \%$ microbial conversion efficiency scFOS application rates. 
inorganic nitrogen. Gradually decreasing the amount of protein in the feed will help determine what percentage protein in the feed will maintain $11.3 \mathrm{mg} / \mathrm{l}$ nitrate nitrogen with only minimal scFOS applications. Ongoing daily scFOS applications are beneficial because scFOS promotes proliferation of non-pathogenic beneficial bacteria.

\section{CONCLUSIONS}

The hypothetical carbon quantification methodology was effective in predicting the amount of carbon required to control inorganic nitrogen. Both 35.1\% MCE and 58.3\% MCE maintained TAN and $\mathrm{NO}_{2}-\mathrm{N}$ at desired levels. The amount of carbon used in the $35.1 \%$ MCR treatment resulted in greater biofloc levels. This required settling to remove excess biofloc, and water to replace what was lost during biofloc removal. Ammonia and nitrites were assimilated before nitrates. This permits flexible carbon application management to maintain good water quality. Accumulated scFOS trends projected forward indicated that ultimately, the MCE rate may not affect the amount of carbon being applied. The 58.3\% MCE treatment had the benefits of reduced organic loading, reduced water replacement, and decreased costs. The 58.3\% MCE treatment produced slightly higher benign $\mathrm{NO}_{3}-\mathrm{N}$ levels.

\section{ACKNOWLEDEGMENTS}

We would like to thank graduate students Jolly Morgan and Ivy McClellan for their help in stocking and harvest of the production trial. We would like to thank technician Wendy Baxter for help in preparing experimental diets, technician Woodie Lawson for assistance in system preparation, and technician Roger Anderson for help in system maintenance.

We would like to acknowledge Colorite Plastics for donating air diffuser hoses, Fritz Industries for providing nitrifying bacteria, Ingredion for providing scFOS, Shrimp Improvement Systems for quantifying small batches of PL's to be stocked, Ziegler Brothers for providing feed and feeders, and XperSea Solution, Inc. for providing training and use of the electronic post larvae counter.

\section{REFERENCES}

Avnimelech, Y. 2009. Biofloc Technology - A Practical Guidebook. The World Aquaculture Society, Baton Rouge, Louisiana, United States.

Churchill, P. and Elmer, D. Hydrogen Sulfide Odor Control in Wastewater Collection Systems. New England Water Environment Association Journal 1999, (33)1:57-63
Crockett, J.K., Lawrence, A.L., Moeckel, J., Lingfelter, B.A, and Patnaik, S. 2012. Ammonia, Nitrite, Nitrate Management Strategies in Zero to Limited Water Exchange Shallow Water Indoor Nursery Production Systems. International Conference of Recirculating Aquaculture, Roanoke, VA

Crockett, J.K., Lawrence, A.L., Kuhn, D.D., 2013. Using the Bioreactor Concept - Shallow Water Nursery System for the Production of Juvenile Shrimp. Aquaculture America 2013, Nashville, TN

Ebeling, J.M., Timmons, M.B., Bisogni, J.J. Engineering Analysis of the Stoichiometry of Photoautotrophic, Autotrophic, and Heterotrophic Removal of Ammonia-Nitrogen in Aquaculture Systems. Aquaculture 2006, 257:346-358.

Kuhn. D.D., Smith, S.A., Boardman, G.D., Angier, M.W., Marsh, L. and Flick, G.J. Chronic toxicity of nitrate to Pacific white shrimp, Litopenaeus vannamei: Impacts on survival, growth, antennae length, and pathology. Aquaculture 2010, (309):109-114.

Lin, Y.C., and Chen, J.C. Acute toxicity of ammonia on $\mathrm{Li}$ topenaeus vannamei Boone juveniles at different salinity levels. Journal of Experimental Marine Biology and Ecology 2001 (259): 109-119.

Lin, Y.C., and Chen, J.C. Acute toxicity of nitrite on Litopenaeus vannamei (Boone) juveniles at different salinity levels. Aquaculture 2003 (224): 193-201.

Prescott, L. M., Harley, J.P., Klein, D.A. 1990. Microbiology, second edition. William C. Brown Publishers, a division of William C. Brown Communications, Inc. Dubuque, IA USA 52001.

Rittmann, B.E., McCarty, P.L. 2001. Environmental Biotechnology Principles and Applications, Edited by Eric Munson. McGraw-Hill Higher Education. McGraw Hill New York, NY, USA.

Schuler, D.J., Boardman, G.B., Kuhn, D.D., and Flick, G.S. Acute Toxicity of Ammonia and Nitrite to Pacific White Shrimp, Litopenaeus vannamei, at Low Salinities. Journal of the World Aquaculture Society 2010, (41)3:438-446

Tseng, I.T., and Chen, J.C. The immune response of white shrimp Litopenaeus vannamei and its susceptibility to Vibrio alginolyticus under nitrite stress. Fish \& Shellfish Immunology 2004, (17):325-333.

US Peroxide on line, 2014. Nitrate Applications for Hydrogen Sulfide Control. http://www.h2o2.com/ 